ELORE (ISSN 1456-3010), vol. 17 - 1/2010.

Julkaisija: Suomen Kansantietouden Tutkijain Seura ry.

[http://www.elore.fi/arkisto/1_10/ajankoht_davydova_1_10.pdf]

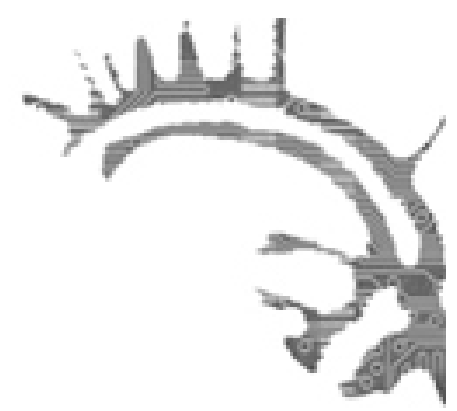

\title{
Ajankohtaista
}

\section{SUOMALAISENA, VENÄLÄISENÄ JA KOLMANTENA ETNISYYSDISKURSSEJA TRANSNATIONAALISSA TILASSA}

\author{
Lectio praecursoria Joensuun yliopistossa 27.11.2009
}

\section{Olga Davydova}

Tutkin väitöskirjassani entisestä Neuvostoliitosta Suomeen suuntautuvaa muuttoliikettä, josta käytetään termiä paluumuutto. Tämä käytäntö, joka alun perin oli kehitetty edistämään Ruotsiin 1960- ja 70-luvulla muuttaneiden suomalaisten, siis Suomen kansalaisten, paluuta Suomeen, laajennettiin koskemaan Neuvostoliiton suomalaisiksi rekisteröityjä henkilöitä sen jälkeen, kun presidentti Koivisto huhtikuussa v. 1990 televisiohaastattelussa oli luonnehtinut inkerinsuomalaisia suomalaisiksi.

Vaikka yleisessä keskustelussa entisestä Neuvostoliitosta ja sittemmin Venäjältä, Virosta, Kazakstanista, Tadzhikistanista ynnä muista uusista valtioista Suomeen muuttaneita ihmisiä edelleenkin halukkaasti mielletään inkeriläisiksi, on tähän muuttoliikkeeseen mahtunut muitakin suomalaista syntyperää olevia ihmisiä - niin sanottujen punikkien, loikkareiden ja amerikansuomalaisten jälkeläisiä - sekä heidän perheenjäseniään, jotka etniseltä alkuperältä voivat edustaa koko entisen Neuvostoliiton kansallisuuskirjoa. Kaiken kaikkiaan paluumuutto on koskenut melko heterogeenista joukkoa ihmisiä. Melkein kahdenkymmenen vuoden aikana paluumuuttomenettelyn myötä Suomeen on muuttanut noin 30000 entisen Neuvostoliiton kansalaista.

Paluumuuton alku liittyy 1980-luvun lopun muutoksiin, neuvostososialismin romahtamiseen. Tässä prosessissa kansallisuudella ja etnisyydellä on ollut suuri rooli. Kansallisuus ja etnisyys politisoituivat kansalaisliikkeissä, jotka johtivat muun muassa uusien kansallisvaltioiden muodostumiseen ja demokraattisten yhteiskuntien rakentamiseen. Neuvostoliiton suomalaisten liikkeellä on ollut osuutensa tässä prosessissa, ja se sai ylirajaisesti vastakaikua Suomessa vaikuttaen siihen, että Neuvostoliiton suomalaiset oltiin valmiit näkemään "kotimaahan" palaavina "omina". Muutoshuuman laannuttua ja talouslaman alettua paluumuuton oikeutusta kuitenkin Suomessa ruvet- 


\section{Olga Davydova: Etnisyysdiskursseja transnationaalissa tilassa}

tiin kyseenalaistamaan. Maahan muuttaneet "inkeriläiset" eivät vastanneet odotusta kulttuurisesta samuudesta eivätkä pystyneet osoittamaan hyödyllisyyttään lamassa kaventuneilla työmarkkinoilla.

Paluumuuttoa säätelevää lainsäädäntöä on kehitetty ja tiukennettu koko 1990- ja 2000-luvun, esittäen yhä yksityiskohtaisempia ja eriytyneempiä sekä eriyttäviä kriteerejä tuleville muuttajille. Kriteerit porrastavat henkilön paluumuuttokelpoisuuden riippuen tämän syntyperästä ja suhteesta Suomeen valtiona sekä määrittävät tarvittavan kielitaidon ja identiteetin. Neuvostoajan yhtenäinen kansallis-etninen kategoria - suomalainen - on paluumuuttomenettelyssä tullut eriteltyä "Suomen kansalaisten jälkeläiseksi" ja "suomalaista syntyperää olevaksi". Viimeksi mainittu tarkoittaa niitä, joilla ei koskaan ollut kansalaisuussidettä Suomeen, siis niin sanottuja inkerinsuomalaisia. Heitäkin eriytetään niihin, jotka sodan aikana ovat palvelleet Suomen armeijassa ja Suomeen evakuoituihin sekä muihin, joilta vaaditaan maahanmuuttovalmennukseen osallistumista ja kielikokeen suorittamista. Lähtöpäähän on muodostunut pitkiä jonoja, joissa etenemiseen viimeisten uudistusten myötä voi vaikuttaa hakijan ammattitaito. Näin paluumuuttopolitiikka on kytketty työperäistä maahanmuuttoa edistävään politiikkaan. Katson, että olemassaolonsa aikana paluumuuttomenettely on osallistunut hierarkkisen kansallisuuden rakentamiseen niin Suomessa kuin Venäjälläkin, siis ylirajaisesti.

\section{Minä TUtKIJANA}

Olen monella tavalla sidoksissa tähän muuttoliikkeeseen henkilökohtaisesti. Olen tullut Suomeen vuonna 1991 paluumuuttajan statuksella Petroskoista. Vuosina 1997-2003, toimiessani Joensuun yliopiston täydennyskoulutuskeskuksen Itäinnova-yksikön kurssinjohtajana, koordinoin Petroskoissa järjestettäviä maahanmuuttovalmennuskursseja. Olen siis ollut paluumuuttomenettelyn kohteena ja sitä toimeenpanevana viranomaisena, toteuttanut paluumuuttoa käytännössä. Vallitsevan käsityksen mukaan minäkin koin tilanteen ristiriitaiseksi, ongelmalliseksi ja tutkimusta vaativaksi. Vuonna 2000 pääsin mukaan ammatillisesti suuntautuneeseen perinteentutkimuksen lisensiaatinkoulutusohjelmaan, mistä lähtien olen perehtynyt paluumuuttoon tutkijana.

Tämä väitöskirja esittää sekä tutkimukseni tuloksia että itse tutkimuksen prosessia. Se käsittelee myös tutkijuuteni muodostumista.

Omaelämäkerrallisen Peili -elokuvan (1974) johdanto-osassa ohjaaja Andrei Tarkovski kuvaa dokumenttielokuvan keinoin puheterapiaa, jossa pahasti änkyttävä nuori mies pääsee estoistaan. Lyhyen, erittäin vaikuttavan hypnoosihoidon jälkeen hänen lääkärinsä sanoo: 'Jos pystyt sanomaan nyt 'Ja mogu govorit, pystyn puhumaan' vapautuneesti ja kovalla äänellä, pystyt loppuelämäsikin puhumaan näin, vapautuneesti ja kovalla äänellä.” Tämän jälkeen mies sanoo: "Ja mogu govorit" - ja ohjaajan kertomus minä-muodossa alkaa.

Tutkimukseni punaisena lankana onkin pohdinta siitä, onko vapautunut, omaehtoinen puhe, valtadiskurssia kyseenalaistava puhe, puhe puhujan itsensä luomasta paikasta mahdollista. Samalla kartoitan ja kuvaan sitä paikkaa, joka on monessa mie- 


\section{Olga Davydova: Etnisyysdiskursseja transnationaalissa tilassa}

lessä ambivalentti. Väitöskirjani johtolauseena on sitaatti Donna Harawayn esseestä Simians, Cyborgs, and Women: "The only way to find a larger vision is to be somewhere in particular. The science question in feminism is about subjectivity as positioned rationality" (Haraway 1991, 196). Objektiivisuuteen pyrkivän tutkimuksen "jumalaisen katseen" vastapainoksi Haraway vaatii tutkijaa pohtimaan ennen kaikkea omaa positioitumista: tieteenalan teoreettisia ja metodologisia sitoumuksia, tutkijan sosiaalista, kulttuurista, sukupuolista, historiallista, tilallista sijoittuneisuutta, joka ehdollistaa tutkimuksen kohteen tarkastelutapaa. Kääntämällä katse sisään/ itseen/ ympäristöön saadaan rehellisempi tutkimustulos. Suvi Ronkaisen $(2004,69)$ sanoin, feministisen tutkimuksen ytimenä on tiedollinen reflektio eli tieteelliselle tutkimukselle esitettävä vaade tietää, mitä tietää ja millä perusteilla tiedon tietona esittää.

Tutkijan, tutkittavan ja tutkimuksen vastaanottajan eli lukijan suhdetta on pohdittu positioitumisen ja dialogisunden käsitteiden avulla. Niin tutkija, tutkittava kuin tutkimuksen vastaanottajakin ovat osa historiallisesti ja paikallisesti muodostuneita valtasuhteita. Tiedon tuottamisen dialogisuuden vaatimus korostaa kaikkien tutkimusprosessin osapuolten toimijuutta. Dialoginen suhde muodostuu Toiseen ja tutkimusprosessissa tutkija, tutkittava ja tutkimuksen vastaanottaja ovat toisilleen näitä Toisia. Puhe minä-paikasta on myös sisäisesti dialogista ja valtasuhteiden läpäisemää. Koen, että paikkani on ollut kansallisuusideologian ja siten paluumuuttomenettelyn suhteen sekä keskuksessa että marginaalissa. Kyetäkseni puhumaan tarvitsin sanoja, käsitteitä.

\section{IDENTITEETTI JA ETNISYYS}

Ajatteluni keskeiseksi käsitteeksi on noussut identiteetin käsite: pohdin identiteetin käyttöä viranomaisretoriikassa, paluumuuttajiksi pyrkivien ihmisten identiteettipuhetta sekä etnisiä ja kansallisia identiteettejä mahdollistavia diskursseja. Paluumuuton kontekstissa näitä ovat kansallisuus- ja etnisyysdiskurssit, jotka toimivat ja vaikuttavat, muodostavat kansallisia ja etnisiä maahanmuuttajasubjekteja ylirajaisesti. Väitöskirjani artikkelit ovat myös pohdintaa etnisyydestä, sen olomuodoista ja myös siitä, onko etnisyys jokin ihmiselämää ratkaisevasti järjestävä ominaisuus vai onko se muodostettua, ja miten se toimii olemisen ja ei-olemisen rajoilla. Pohdin, mistä asiantiloista voi puhua etnisyyden kautta, missä muodoissa etnisyys artikuloituu ja milloin.

Tässä suhteessa työni on puheenvuoro vanhassa, mutta edelleenkin ajankohtaisessa teoreettisessa keskustelussa etnisyyden erilaisista ymmärtämisistä. Primordialististisena ymmärrettynä etnisyys nähdään yksilöistä nousevana identiteettinä ja olemassa olevana yhteiskunnan järjestämisen peruskategoriana. Instrumentalistisen käsityksen mukaan yksilö voi käyttää etnisyyttä hänen tahtonsa ja tarpeensa mukaan yhteiskunnallisena resurssina. Konstruktionistisessa, postmodernissa etnisyyden tulkinnassa "etnisyys" puolestaan liukenee sarjaan identifikaatioliikkeitä. Se on yksi mahdollisista, toistensa kautta rakentuvista sosiaalisesti muodostuneista identiteeteistä.

Pidän mahdollisena käsittää etnisyyttä diskurssina, joka viittaa kansaan, ryhmään, kulttuuriin, alkuperään, alueeseen ja valtasuhteeseen. Nationalistisesta diskurssista poiketen etnisyydellä viitataan useimmiten vähemmistöasemassa oleviin, vaikkakin rajan vetäminen nationalistisen ja etnisyysdiskurssin välille on ongelmallista. Etni- 


\section{Olga Davydova: Etnisyysdiskursseja transnationaalissa tilassa}

syysdiskurssin käyttäjistä riippuu sen sävy ja suuntautuneisuus. On ilmeistä, että eri yhteiskunnalliset toimijat voivat käyttää erilaisia etnisyyden diskursseja.

Väitöskirjan kolme ensimmäistä artikkelia oli kirjoitettu vuosina 2001-2004 Etniskulttuuriset toisendet voimavarana ja rajoitteena -tutkimusprojektin aikana. Artikkeleissa pohdin "suomalaisen identiteetin" käyttöä paluumuuttokelpoisuuden kriteerinä, suomalaisuuden diskurssia, joka muodostaa puitteet paluumuuttajiksi pyrkivien ihmisten identiteettipuheelle. Kolmen ensimmäisen artikkelin haastatteluaineisto on kerätty toimiessani maahanmuuttovalmennuskurssien koordinaattorina Petroskoissa. Artikkeleissa tarkastelen, kuinka suomalaisuuden standardi toimii ylirajaisesti ja kuinka paluumuuttajiksi pyrkivät ihmiset toimivat vastatakseen sitä.

Sysäyksenä Venäjältä Suomeen muuttavien ihmisten identiteettipuheen tutkimiselle minulla on toiminut viranomaisten teksteissä ja maahanmuuttokäytännöissä 1990-luvun lopussa ja 2000-luvun alussa viljelty identiteetin käsite. Ryhdyin kyseenalaistamaan tämän käsitteen käyttöä maahanmuuttomenettelyssä ja selvittämään sen ideologista taustaa. Stuart Hallin (1999) Identiteetti-niminen artikkelikokoelma tarjosi toisenlaisen näkökulman identiteettiin, käsitteen historiaan, identiteettipolitiikkoihin ja koko keskusteluun sen ympärillä. Hallin käsitys identiteetistä on erilainen kuin sen ajan "inkeriläiskeskustelussa" ja toiminnassa vallalla ollut: diskursiivisiin identifikaatiosarjoihin liukuva, tilannesidonnainen ja siten fragmentaarinen, saavuttamaton kokonaisuuden kaipuu ja pakko - eikä ryhmän "historiaan" ja "kulttuuriin" perustuva ryhmähengen ja kuulumisen luonnollinen rakentuminen.

Hallin käsitys diskursiivisesti muodostuvasta identiteetistä ja identifioitumisesta johti myös Michel Foucaultin ajatteluun perehtymiseen. Käsitän työssäni diskurssin ontologisena tietoa ja subjektia tuottavana normatiivisena tietojärjestelmänä. Diskurssi määrittelee puheen kohteet, niiden väliset suhteet, puhumisen tavat ja käsitteet ja tarjoaa puhujalle position, jonka ottamalla hän muuttuu diskurssin subjektiksi. Diskurssi siis viittaa "tapoihin muodostaa sosiaalisissa käytännöissä tietoa, subjektiviteetin muotoja ja valtasuhteita, jotka kuuluvat olennaisesti näihin tieto(järjestelmiin) ja niiden välisiin suhteisiin. Diskurssit ovat enemmän kuin ajattelu- tai merkityksen tuottamistapoja. Ne muodostavat hallintaansa tavoittelemien subjektien ruumiiden, tiedostavan ja tiedostamattoman mielen ja tunne-elämän "luonteen" (Weedon 1987, 108).

\section{YliRAJAISUUS}

Toinen tärkeä teoreettinen näkökulma tuli tutkimukseeni siirryttyäni Multisited Lives in Transnational Russia. Questions of Identity, Belonging and Mutual Care -projektiin. Hankkeen teoreettisena pohjana oli transnationaali näkökulma, joka ei näe maahanmuuttajaa "uutena" "vastaanottavassa" yhteiskunnassa, vaan päinvastoin vanhojen ja uusien sosiaalisten verkostojen jäsenenä. Verkostot toimivat ylirajaisesti, sillä yhteydet lähtömaan ihmisiin eivät katkea maastamuuton myötä.

Transnationaalisuuden (transnational) käsite on otettu käyttöön eräänlaiseksi vastakohdaksi kansainvälisen (international) käsitteelle, jolla viitataan valtioiden välillä tapahtuviin prosesseihin. Transnationaalin vastineeksi suomen kielessä ovat vahvistumassa termi ylirajainen, jolloin huomio kiinnittyy monenlaisten rajojen ylittämiseen, mutta 


\section{Olga Davydova: Etnisyysdiskursseja transnationaalissa tilassa}

samalla niiden jatkuvaan läsnäoloon ylirajaisessa elämässä. Transnationaalin käsitteellä siis viitataan niihin toimijoihin (yksilöihin, sukulaisryhmiin, etnisiin ryhmiin, yrityksiin, sosiaalisiin ja poliittisiin liikkeisiin yms.) ja verkostoihin, jotka toimivat valtiollisten ja kansallisten rajojen yli ainakin jossain määrin valtioista riippumatta. Toisaalta transnationaalin käsite on ambivalentti: periaatteessa sen avulla pyritään kyseenalaistamaan valtioiden ja kansakuntien määräävää roolia globalisoituvassa maailmassa, toisaalta itse termi korostaa kansallisuuden, kansakunnan ja erinäisten rajojen jatkuvaa läsnäoloa. Transnationaalisuuden ajattelu kiinnittää paradoksaalisesti huomiota siihen, minkä se ikään kuin kieltää, nimittäin kansakuntaan ja erinäisiin rajoihin.

Ulrich Beck (1999, 69-73, 134-141) on luonnehtinut maahanmuuttajien luomia uusia kulttuurisia ja sosiaalisia tiloja "kolmansiksi" tiloiksi, jotka eivät palaudu täydellisesti lähtö- eivätkä kohdemaahan, vaan ovat jotakin siltä väliltä, sekä että. Näitä hybridejä sosiaalisia ja kulttuurisia tiloja Avtar Brah (1998) on kuvaillut diasporatilan käsitteen avulla. Diasporatila kuvaa nykymaailmaa jatkuvan liikkeen ja paikallaolon väliseksi suhteeksi, joka kyseenalaistaa ja suhteellistaa kaikki vakiintuneet käsitteet: alkuperäisen, natiivin, maahanmuuttajan, oman ja vieraan. Deborah Brycesonin ja Ulla Vuorelan $(2002,5)$ mukaan diasporatila "viittaa muuttavien ihmisten, pääomien, tavaroiden ja kulttuurin nykytilan risteysalueeseen, jossa koetaan eri rajojen ylitysten tai jopa rikkomusten taloudellisia, kulttuurisia ja poliittisia merkityksiä; missä muodostuu transkulttuuristen identiteettien nykymuodot; missä kuuluvuus ja toiseus ovat omaksuttuja ja kyseenalaistettuja." Inderpal Grewal $(2005,23)$ on korostanut, että diasporatilassa olevien ylirajaiset suhteet on tutkittava myös vallan näkökulmasta: mitkä diskurssit muodostavat näitä verkostoja ja mitä subjektipositioita ne tarjoavat, minkälaisia maahanmuuttajasubjekteja mahdollistavat. Toisen tutkimusprojektin aikana kirjoitetuissa artikkeleissa tarkastelin perherituaalia, paluumuuttajan hautajaisia sekä Suomessa asuvien venäjänkielisten nettikeskusteluja ja laajemmin mediakäyttöä. Olen tuonut esille joitakin suomalais-venäläisen diasporatilan muodostavia valtasuhteita, diskursseja, joita ihmiset käyttävät rakentaessaan kuulumisia, sekä ihmisten toimijuutta niiden valtakentässä.

Paluumuuttokäytännön ja sen määrittämän kansallisuuskäsityksen lisäksi maahanmuuttajuutta muokkaavana diskurssina näen työperäisen maahanmuuton diskurssin ja sen tarjoamat subjektipositiot. Viimeisessä artikkelissa tarkastelen muun muassa uuden venäläisyyden diskurssin toimintaa ylirajaisesti. Aineiston tähän ovat tarjonneet Virossa huhtikuussa 2007 toteutettu neuvostosotilaan muistomerkin siirto sekä siitä virinnyt keskustelu sähköisessä mediassa.

\section{INTERNET TRANSNATIONAALINA TILANA}

Eräänä konkreettisena transnationaalisuuden tilana käsittelen Internetin virtuaalista tilaa. "Uuden teknologian valtava kyky ylittää kansallisia rajoja ja fyysisiä tiloja" (Hannerz 1998, 245), hybridisyyden luvattu alue vaikutti alussa ihanteelliselta avulta transnationaaleille suhteille. Internetin luonne on kahtalainen, se on samalla julkinen ja yksityinen tila, jossa on mahdollista artikuloida valtadiskurssista poikkeavia identiteettejä. Pidin tärkeänä esittää venäjänkielisten maahanmuuttajien itsensä luomaa 


\section{Olga Davydova: Etnisyysdiskursseja transnationaalissa tilassa}

mediatilaa, jossa he voivat puhua enemmän tai vähemmän omaehtoisesti.

Käsitän tutkimani $\langle$ www.suomi.ru $\rangle$ - internet-foorumin puolijulkiseksi, anonyymiksi, avoimeksi kommunikaatiotilaksi, joka muun muassa antaa mahdollisuuden verkostojen muodostamiseen ennalta tuntemattomien ihmisten välille. Foorumi toimii ylirajaisesti, sen rekisteröityneinä käyttäjinä on Suomessa, Venäjällä, Saksassa, Israelissa, Valkovenäjällä ynnä muissa maissa asuvia ihmisiä. Internet ei tarjoa mahdollisuutta olla yhteydessä ainoastaan lähtöyhteisöön, vaan sitä kautta on mahdollista osallistua verkostoihin, jotka eivät käy yhteen maahanmuuttomaassa muodostuvaan maahanmuuttajayhteisön ja primääristen verkostojen kanssa. Tämä koetaan tärkeäksi vapautta lisääväksi seikaksi usein rajoitetussa paikallisessa maahanmuuttajayhteisössä. Tutkimani foorumin voi nähdä myös tekstinä, joka on intertekstuaalisessa suhteessa moneen muuhun tekstiin ja on syntynyt tietyssä ajallisessa ja sosiaalisessa kontekstissa. Viestien ja linkkien lukeminen on kiinnostavaa itsessään, ja foorumin teksti muodostaa osan venäjän- ja suomenkielistä mediatilaa. Foorumi voi kiinnostaa käyttäjää tekstikokonaisuutena, eikä välttämättä sosiaalisena ympäristönä.

Tutkin etnisyyttä verkkoympäristössä sen tekstuaalisessa muodossa. Nettiaiheisissa artikkeleissa olen pyrkinyt sitomaan tutkimani keskustelut yhteiskunnalliseen ja kulttuuriseen kontekstiin. En ollut kiinnostunut yksittäisten keskustelijoiden mielipiteistä, vaan niiden osallisuudesta laajempaan diskurssiin. Internet-tila on yhtä lailla yhteiskunnallisen vallan läpitunkema kuin mikä tahansa muu yhteiskunnallisen ja kulttuurisen toiminnan alue, ja käyttäjien puhe tai muu toiminta on merkitysten luomista ja niiden tulkintaa yhteiskunnallisessa diskursiivisessa ympäristössä. "Elämä päätteellä" sisältää kamppailuja identiteeteistä, merkityksistä ja itsestä. Nettisivuilla toteutetaan etnistettyä ja etnistävää, sukupuolitettua ja sukupuolittavaa identiteettipolitiikkaa. Nettikeskustelujen analyysi voi siten paljastaa jotakin kulttuurisesta toiminnasta laajemmin.

Nähdäkseni transnationaali mediatilan subjekti eroaa kansallisesta kahdenlaisen sidonnaisuutensa vuoksi. Hän on tavallaan subjekti molemmissa kansallisissa tiloissa, jotka ovat puolestaan ristiriitaisia, monista diskursseista koostuvia. Nämä monet diskurssit tarjoavat subjektipositioita, jotka voivat olla samanaikaisesti keskeisiä ja marginaalisia, ne sulkevat sisään ja lyövät pois valikoivasti. Näyttää siltä, että ylirajaisuuden oloissa "lähtömaan" mediatilan merkitys yksittäiselle käyttäjälle kasvaa, kun omakohtainen kokemus lähtöpaikoista ohenee. Yksittäisen käyttäjän luoma ja kokema ylirajainen mediatila voidaan mielestäni nähdä eräänä hybridisenä "kolmantena tilana". Se ei palaudu lähtömaan tai kohdemaan fyysiseen eikä mediatilaan; se on hajakeskeinen, ristiriitainen ja konfliktinen ja sen osallistujat kirjoittavat sitä itselleen ja "asustavat" sitä enemmän tai vähemmän näkyvinä.

\section{YHTEENVETO}

Yhteenvetona voin sanoa, että tutkimuksessani olen tuonut esille niin identiteettejä tuottavaa diskursiivista valtaa kuin korostanut, etten pyri määrittelemään haastattelemieni ihmisten tai internet-keskusteluihin osallistuvien kirjoittajien "perimmäisiä identiteettejä’. Tuon esille puhetapoja, joilla subjektivoitumista tutkimuksen aikaisiin 
Olga Davydova: Etnisyysdiskursseja transnationaalissa tilassa

diskursseihin rakennettiin. Tutkimukseni on osittainen, en ole pyrkinyt kaikenkattavuuteen. Mihail Bahtin on vuoden 1943 muistinpanoissa (Bahtin 2000, 235) kiteyttänyt dialogisen suhteen toiseen "rakkaudeksi", joka tunnustelee toisen rajoja: "Rakkaus hellii ja hyväilee rajoja; rajat saavat uusia merkityksiä. Rakkaus ei puhu kohteestaan sen ollessa poissa, vaan puhuu siitä sen itsensä kanssa". Humanistisen tutkimuksen ideaalina on sanoa kohteestaan jotakin niin, ettei tutkimus toimisi monologisoivasti. "Väkivaltainen sana edellyttää puuttuvan ja vaitonaisen kohteen, joka ei kuule eikä vastaa" (Bahtin 2000, 235). Tunnustan oman tutkimukseni jonkinasteisen väkivaltaisuuden. Tutkimus on ainakin jonkin verran monologisoiva teko: olen tavallaan "sulkenut" tutkittavien ääniä ja pyrkinyt tuomaan esille, miksi olen tehnyt näin. En silti näe, ettei tätä olisi voitu tehdä toisin. Itse asiassa jokaista tekstiä voi dialogisoida edelleen ja hakea siitä uusia merkityksiä ja tulkintoja.

\section{KirJallisuUs}

BAHTIN, MIHAIL 2000: Avtor i geroi. K filosofskim osnovam gumanitarnyh nauk. SanktPeterburg: Izdatel'stvo "Azbuka".

BECK, ULRICH 1999: Mitä globalisaatio on? Virhekë̈sityksiä ja poliittisia vastanksia. Tampere: Vastapaino.

BRAH, AVTAR 1998: Cartographies of Diaspora. Contesting identities. London \& New York: Routledge.

BRYCESON, DEBORAH \& VUORELA, ULLA 2002: Transnational Families in the Twenty-first Century. - Bryceson, D. \& Vuorela, U. (toim.) The Transnational Family. New European Frontiers and Global Networks. Oxford \& New York: Berg.

GREWAL, INDERPAL 2005: Transnational America. Feminisms, Diasporas, Neoliberalisms. Durham, NC: Duke University Press.

HALL STUART 1999: Identiteetti. Tampere: Vastapaino.

HANNERZ, ULF 1998: Transnational Research. - Russel Rernard, H. (toim.) Handbook of Methods in Cultural Anthropology. Walnut Creek: Altamira Press.

HARAWAY, DONNA J. 1991: Simians, Cyborgs, and Women: The Reinvention of Nature. London: Free Association Books.

RONKAINEN, SUVI 2004: Kvantitatiivisuus, tulkinnallisuus ja feministinen tutkimus. - Liljeström, M. (toim.) Feministinen tietäminen: keskustelua metodologiasta. Tampere: Vastapaino. s. 44-69.

WEEDON, CHRIS 1987: Feminist Practice and Poststructuralist Theory. Worchester: Blackwell.

Filosofian tohtori Olga Davydova työskentelee nuorempana tutkijana Karjalan tutkimuslaitoksessa Joensuussa. 